Avenues of Participation 
PRINCETON STUDIES IN MUSLIM POLITICS

Dale F. Eickelman and James Piscatori, editors 


\section{Avenues of Participation}

FAMILY, POLITICS, AND NETWORKS IN

URBAN QUARTERS OF CAIRO

- DIANE SINGERMAN •

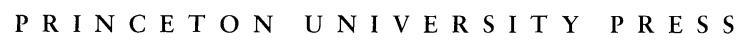

P R I N C E T O N, NE W J E R S E Y 
Copyright $(\subset) 1995$ by Princeton University Press

Published by Princeton University Press, 41 William Street,

Princeton, New Jersey 08540

In the United Kingdom: Princeton University Press,

Chichester, West Sussex

All Rights Reserved

Library of Congress Cataloging-in-Publication Data

Singerman, Diane.

Avenues of participation : family, politics, and networks

in urban quarters of Cairo / Diane Singerman.

p. cm. - (Princeton studies in Muslim politics)

Includes bibliographical references (p. ) and index.

ISBN 0-691-08654-0 (CL)

1. Political participation-Egypt-Cairo. 2. Family-Egypt-

Cairo. 3. Households-Egypt-Cairo. 4. Informal sector

(Economics)-Egypt-Cairo. I. Title. II. Series.

JS7782.S55 $1995 \quad 323^{\prime} .042^{\prime} 096216$-dc20 $94-19060 \quad$ cip

The jacket photo and photos on pages 26 and 28 courtesy of

John Waterbury. All other text photos are by the author.

This book has been composed in Laser Sabon

Princeton University Press books are printed on acid-free paper and meet the guidelines for permanence and durability of the Committee on Production Guidelines for Book

Longevity of the Council on Library Resources

Printed in the United States of America

$\begin{array}{llllllllll}1 & 3 & 5 & 7 & 9 & 10 & 8 & 6 & 4 & 2\end{array}$ 
TO MY MOTHER, PHYLLIS SINGERMAN,

- AND TO THE MEMORY OF MY FATHER, •

SOL SINGERMAN 
